\title{
External ophthalmomyiasis caused by the sheep bot Oestrus ovis L.
}

\author{
D. WONG
}

From St Paul's Eye Hospital, Old Hall Street, Liverpool 3

SUMMARY A case is reported of infestation of the conjunctiva by maggots of the fly Oestrus ovis $\mathrm{L}$.

Oestrus ovis $\mathrm{L}$. is one of a number of species of flies whose larvae cause infestation or myiasis in man. The larvae, or maggots, are obligatory parasites requiring at least some period of development in living tissue. The usual host is sheep, and thus the name sheep bot fly. The fly deposits its eggs in flight near the mucus membrane of the host, usually external nares or conjunctiva.

\section{Case report}

A 17-year-old girl presented to the Casualty Department of St Paul's Eye Hospital, Liverpool, with a foreign body sensation in the right eye for 2 days. Two days previously she was on a beach in Palma Nova in Majorca. She thought sand had blown into her eye. She did not remember ever having been struck in the eye or face by any insects.

On examination the conjunctiva of the right eye was mildly congested. On slit-lamp examination 3 maggots or larvae were found in the conjunctival sac. The larvae were transparent and small, measuring about $1 \mathrm{~mm}$ in length, visible only with high magnification on the slit-lamp. Interestingly, the larvae were 'photophobic', moving away from the light of the slit-beam to hide in the depth of the conjunctival sac.

The larvae were removed with forceps and stored in a formalin solution. A lacrimal sac wash-out was attempted but later abandoned because of a tight punctum. Chloramphenicol drops $0.5 \%$ were instilled. Fundal examination revealed no abnormality, and the anterior chamber was quiet.

The same evening the patient returned and complained of a foreign body sensation in the right eye again. This time she described it as 'something crawling' in her eye. Another maggot was found and removed. Cocaine can apparently paralyse the

Correspondence to Dr D. Wong, Moorfields Eye Hospital, City Road, London EC1V 2PD. maggots, facilitating observation and removal. All maggots were subsequently sent to the Liverpool School of Tropical Medicine for examination and have been identified as the larvae of Oestrus ovis L.

\section{Discussion}

The larvae of Oestrus ovis usually mature in the mucus membrane and then drop to the ground and pupate. ${ }^{1}$ In the human conjunctiva they can cause a great deal of irritation, lacrimation, pain, inflammation, and acute mucopurulent conjunctivitis from secondary bacterial infection, giving rise to the clinical manifestation of external ophthalmomyiasis. ${ }^{2}$

However, they are also equipped with oral hooks and spines (Fig. 1) and can burrow into the lids or

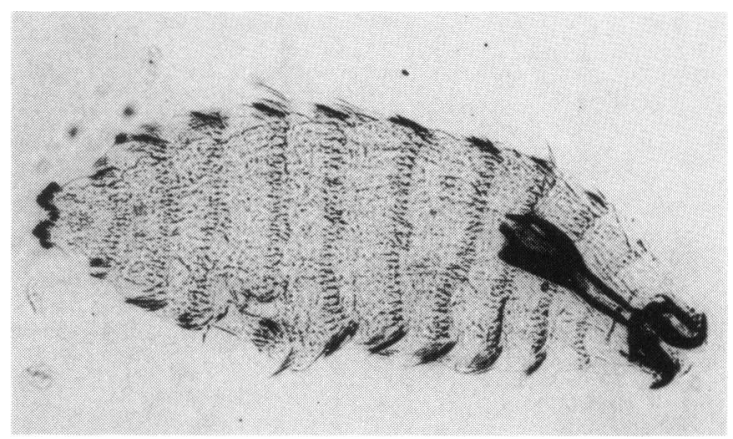

Fig. 1 Larva of Oestrus ovis $L$.

penetrate the globe through the sclera into the inner structures of the eye, causing internal ophthalmomyiasis. The consequent panuveitis is often severe and the visual prognosis poor. ${ }^{34}$ Debilitated elderly people and poorly nourished children are particularly susceptible to internal ophthalmomyiasis. In very severe cases, particularly in tropical countries, the maggots eat into the tissues and convert the whole orbit into a crawling pit. ${ }^{5}$ 
This is the first known report of an imported case of external ophthalmomyiasis in the United Kingdom caused by Oestrus ovis $\mathrm{L}$. The sheep bot fly is widely reported in the Mediterranean and Middle Eastern countries. Between January 1977 and December 1978 80 human cases of ophthalmomyiasis were reported in Benghazi, Libya. ${ }^{6}$ The oestrus fly can apparently inhabit many different geographic and climatic conditions, but it is only sporadically reported in welldeveloped countries such as America and Australia. ${ }^{7-10}$ Poor health of sheep and farmer, close contact between animals and man, and generally poor living conditions may be contributing factors to the likelihood of human infestation. It is interesting to note that no indigenous cases in man have yet been recorded in the United Kingdom despite a substantial sheep population.

I thank Mr T. D. H. Gray and Mr S. I. Davidson for their kind help and advice.

\section{References}

1 Zumpt F. Myiasis in man and animal in the Old World. London: Butterworth, 1965: 174-9.

2 Hennessy DJ, Sherrill JW, Binder PS. External ophthalmomyiasis caused by Oestrus ovis. Am J Ophthalmol 1977; 84: 802-5.

3 Hunt EW Jr. Unusual case of ophthalmomyiasis interna posterior. Am J Ophthalmol 1970; 70: 978-80.

4 Rakusin W. Ocular myiasis interna caused by the sheep nasal bot fly (Oestrus ovis L.). S Afr Med J 1970; 44: 1155-7.

5 Duke-Elder S. System of Ophthalmology. London: Kimpton, 1965: 8: 426-9.

6 Dar MS, Amer MB, Dar FK, Papazotos V. Ophthalmomyiasis caused by the sheep nasal bot, Oestrus ovis larvae, in the Benghazi area of Eastern Libya. Trans R Soc Trop Med Hyg 1980; 74: 303-6.

7 Freney LC, Fox HC. External ophthalmomyiasis caused by Oestrus ovis L. in Queensland. Med J Aust 1974; i: 310-1.

8 Brown HS Jr, Hitchock JC Jr, Foos RY. Larval conjunctivitis in California caused by Oestrus ovis L. Californ Med 1969; 111: 272-4.

9 Cher I. External ophthalmomyiasis in Australia. Med J Aust 1968 ; ii: 335.

10 Priour DJ. Ocular myiasis in a Texas sheep shearer. Tex Med 1976; 10: 1387-9. 